changes in the placenta has been recognised for many years, but the precise correlation between the origin of additional haploid complements and these changes has been made only recently: all paternally derived triploids are partial moles whereas only a few maternally derived triploids are molar. ${ }^{8}$ Our observation is not an exception to this general rule. In these conditions it is difficult to implicate the HLA system in the mechanism leading to the development of a partial hydatidiform mole in the presence of two paternal and one maternal set.

The survival or expulsion of an aneuploid fetus seems to depend on various factors, such as the existence of serious malformations which interrupt embryogenesis at an early stage ${ }^{1}$ or hormonal factors. In chromosomal abnormalities the placenta has varying degrees of defective endocrine function which results in embryonic death. ${ }^{9}$ Here it should be observed that the development of hydatidiform mole in triploid conceptuses does not change the gestational age of fetal death but favours the retention of the fetus after death. ${ }^{10}$ Another factor is maternal age, in that it is possible that older mothers are more tolerant of the aneuploid zygote. ${ }^{11} \mathrm{We}$ are thus led to consider the possibility that immunogenetic similarity between the aneuploid fetus and the mother may also favour the continuation of the pregnancy.

We thank Mrs A M Saunieres for technical assistance and P Brewer for help with translation.

\section{References}

1 Boué JG, Boué A. Chromosomal anomalies in early spontaneous abortion (their consequences on early embryogenesis and in vitro growth of embryonic cells). In: Gropp A, ed. Current topics in pathology. Developmental biology and pathology. Vol 62. Berlin, Heidelberg:? Springer, 1976:193-208.

2 de Grouchy J, Roubin M, Risse JC, Sarrut S. Enfant triploïde $(69, \mathrm{XXX)}$ ayant vécu neuf jours. Ann Geneto (Paris) 1974; 17:283-6.

3 David M, Chambon A, Laurent C, et al. La triploïdie $\frac{\bar{C}}{\bar{\omega}}$ chez l'enfant. I. Etude du phénotype. A propos d'une? observation de triploïdie en mosaïque $46, \mathrm{XX}, 69, \mathrm{XXY} \stackrel{\mathbb{\Omega}}{\Omega}$ Pédiatrie 1975;30:281-98.

4 Niebuhr E. Triploidy in man. Cytogenetical and clinical aspects. Hum Genet 1974;21:103-26.

5 Deligdisch L, Legum C, Peyser MR, Toaff R. Cyclopia associated with triploidy and hydatidiform mole: a case $\vec{\omega}$ report. Teratology 1978;18:257-62.

6 Emberger JM, Marty-Double C, Pincemin D, Caderas de Kerleau J. Holoprosencéphalie par triploïdie 69, XXXO chez un foetus de 5 mois. Ann Genet (Paris) 1976;19:191-3Nㅗ

7 Boué J, Couillin P, Boué A. Mechanisms of triploidy:Clin Genet 1981;19:493.

8 Jacobs PA, Szulman AE, Funkhouser J, Matsuura JS, Wilson CC. Human triploidy: relationship betweers parental origin of the additional haploid complement and development of partial hydatidiform mole. Ann Hum Genet $1982 ; 46: 223-31$.

9 Boué J, Morer I, Vignal P. Essai de définition d'urE coefficient de risque d'anomalie chromosomique eI début de grossesse. J Genet Hum 1980;28:149-53.

10 Szulman AE, Philippe E, Boué JG, Boué A. Humarco triploidy: association with partial hydatidiform mole and non molar conceptuses. Hum Pathol $1981 ; 12: 1016-81$ 1:

11 Aymé S, Lippman-Hand A. Maternal age effecto aneuploidy: does altered embryonic selection play a r Am J Hum Genet 1982;34:558-65.

Correspondence and requests for reprints to $\operatorname{Dr} \mathrm{J} \frac{\mathrm{\varpi}}{\mathrm{\phi}}$ Lambert, Laboratoire d'Histologie, Embryologie, eQ Cytogénétique, Faculté de Médecine, Chemin d $\vec{ङ}$ Vallombrose, 06000 Nice, France.

\title{
Concordant monozygotic twins with bilateral renal agenesis
}

\author{
J R W YATES*, G MORTIMER + , J M CONNOR*, AND JANET E DUKE $\dagger$ \\ *The Duncan Guthrie Institute of Medical Genetics, Yorkhill, Glasgow G3 8SJ; and \\ †the Glasgow Royal Maternity Hospital, Rottenrow, Glasgow G4 ONA.
}

SUMMARY We report the unique observation of monozygotic twins concordant for bilateral renal agenesis.

\section{Case report}

Both parents were 25 years of age and in good health. They were unrelated and there was no

Received for publication 1 June 1983. Accepted for publication 1 July 1983. family history of renal tract abnormalities. The mother's first pregnancy had resulted in a health male infant born by Caesarean section after failed forceps delivery. In this, her second pregnancyo twins were diagnosed by ultrasound at 15 week gestation and the decision was taken to deliver then by elective Caesarean section. She remained we throughout an uneventful pregnancy and there waso no history of exposure to drugs or other know $\bar{P}$ teratogens. A second ultrasound examination at 28 
weeks failed to detect any abnormality. Following the spontaneous onset of labour at 36 weeks' gestation an emergency Caesarean section was carried out. Both twins were breech presentation and very little liquor was present. The first twin, a girl, weighed $2020 \mathrm{~g}$ and died after 20 minutes. The second twin, also a girl, weighed $2050 \mathrm{~g}$ and was stillborn. Both had typical Potter's facies, large spade-like hands, and talipes equinovarus. Twin 1 had severe flattening of the right side of the skull and posterior elongation of the occiput. Twin 2 had a similar deformity affecting the left side of the skull. The single placenta weighed $530 \mathrm{~g}$ and microscopy confirmed that the membranes were diamniotic and monochorionic. Amnion nodosum was present.

Necropsy findings were similar in both infants. There was bilateral renal agenesis with complete absence of the ureters and bladder. The fallopian tubes and uterus were hypoplastic. Normal ovaries and female external genitalia were present. The lungs were hypoplastic and in twin 1 the right middle lobe was absent. Naked eye and radiological appearances suggested frontal craniostenosis but this was not confirmed histologically. Twin 1 had a bony defect in the parietal region of the skull. Both twins were blood group $\mathrm{O}$ Rhesus positive.

\section{Discussion}

Levin ${ }^{1}$ in 1952 described uniovular male twins discordant for bilateral renal agenesis and, reviewing the literature in 1954, Davidson and Ross ${ }^{2}$ found another six discordant twin pairs of unstated zygosity. A large family study of bilateral renal agenesis by Carter et $a l^{3}$ included five male index cases who were twin-born. One co-twin with a form of unilateral renal agenesis was thought to be monochorionic. The remaining four co-twins were unaffected. Two of these were probably monozygotic and two were of unstated zygosity. A bilateral case whose monozygotic co-twin had unilateral agenesis has also been reported by Mauer et al. ${ }^{4}$ Concordant monozygotic twins with unilateral renal agenesis have been described, ${ }^{5}$ but we are not aware of any reports of twins concordant for bilateral renal agenesis. At least 24 families have been described in which a patient with bilateral renal agenesis has had a non-twin sib or other near relative with bilateral or unilateral renal agenesis or total renal dysplasia. $^{367}$ This suggests a genetic component in the aetiology of bilateral renal agenesis and also a genetic relationship with unilateral renal agenesis and total renal dysplasia.

Carter $e t a l^{3}$ have pointed out that the recurrence rate in bilateral renal agenesis is too high to be explained on the basis of multifactorial inheritance, unless estimates of the birth frequency are much too low. Single gene defects may account for some cases and non-genetic factors may well be involved in others. Schinzel et $a l^{7}$ reported bilateral renal agenesis affecting two male infants whose parents were cousins. However, increased consanguinity is not usually a feature of this condition and there is little evidence for autosomal recessive inheritance unless the renal defect is part of a distinct syndrome. Kohn and Borns ${ }^{8}$ described a man with an absent right kidney whose daughter and first cousin had bilateral renal agenesis and whose sister had unilateral renal agenesis. Further evidence in favour of an autosomal dominant entity with incomplete penetrance being responsible for at least some cases of bilateral renal agenesis comes from the finding of unilateral renal agenesis or hypoplasia in the parents of index cases screened for renal anomalies by ultrasound. ${ }^{3}$

The finding of bilateral renal agenesis in monozygotic twins is most readily explained on a genetic basis, but identical twins share more than their genome and exposure to a common environmental factor during fetal life cannot be excluded.

The authors are most grateful to Dr $\mathbf{J}$ L Price and Dr Margaret MacGregor for permission to report this case.

\section{References}

1 Levin H. Bilateral renal agenesis. J Urol 1952;67:86-91.

2 Davidson WM, Ross GIM. Bilateral absence of the kidneys and related congenital anomalies. J Pathol Bacteriol $1954 ; 68: 459-74$.

${ }^{3}$ Carter CO, Evans K, Pescia G. A family study of renal agenesis. J Med Genet 1979;16:176-88.

4 Mauer SM, Dobrin RS, Vernier RL. Unilateral and bilateral renal agenesis in monoamniotic twins. $J$ Pediatr 1974;84:236-8.

5 Waardenburg PJ. Einseitige Aplasie der Nieren und ihrerAbfuhrwege bei beiden eineiigen Zwillingspaarlingen. Acta Genet Med Gemellol (Roma) 1952;1:317.

6 Pashayan HM, Dowd T, Nigro AV. Bilateral absence of the kidneys and ureters. Three cases reported in one family. J Med Genet 1977;14:205-9.

7 Schinzel A, Homberger C, Sigrist T. Bilateral renal agenesis in two male sibs born to consanguineous parents. J Med Genet 1978;15:314-6.

8 Kohn G, Borns PF. The association of bilateral and unilateral renal aplasia in the same family. J Pediatr 1973; 83:95-7.

Correspondence and requests for reprints to $\mathrm{Dr}$ J R W Yates, The Duncan Guthrie Institute of Medical Genetics, Yorkhill, Glasgow G3 8SJ. 